\section{Fundamental and applied researches in practice of leading scientific schools}

journal homepage: http://farplss.org

\title{
Implementation of the optimization program for the development of social expectations of personality (Illustrated by an example of the project «Leader's School»)
}

\section{Popovych}

\section{ORCID 0000-0002-1663-111X}

\section{Kherson State University, Kherson, Ukraine}

Article info

Received 22.09.2018

Accepted 31.10.2018

Kherson State University, Kherson, Ukraine

Попович I. C. (2018). Впровадження програми оптимізації розвитку соціальних очікувань особистості (на прикладі проекту «Школа лідера») Fundamental and applied researches in practice of leading scientific schools, 29 (5), 45-52.
Popovych, I. (2018). Implementation of the optimization program for the development of social expectations of personality (Illustrated by an example of the project «Leader's School»). Fundamental and applied researches in practice of leading scientific schools, 29 (5), 45-52.

The article presents the full cycle from development and implementation to the complete coverage and analysis of the results of the program of optimization of the development and psychocorrection of social expectations of personality, by an example of the project «Leader's School» for the first time. A retrospective and comparative analysis of the project implementation experience is presented. The essence of stages of program development is revealed, psychological content parameters of social expectations of personality are investigated. A considerable amount of psychological content parameters, related to the motivational structure of the personality, sense of life orientations, subject control and exspectometric features has been analyzed. The program has been implemented, which has contributed to the positive dynamic changes in cognitive and behavioral readiness for the intended course of events, which in turn allowed the participants of the project group to be able to assess the future perspective, comprehend the content and organizational peculiarities of future professional activity, «take on the role of future work», which made adjustments to social expectations of the subjects, and affected the design of the expected future model. It was assumed that a significant proportion of students turned out to be unprepared to rapidly change their status, which was reflected on the level of social psychological peculiarities of the expected attitude of the individual towards participants in interpersonal interaction $(\mathrm{Tp}=16,00 ; \mathrm{Tn}=44,00 ; \mathrm{p} \geq 0,05)$. It is established that the process of formation of emotional readiness requires long-term external interventions.

The author's position is that the developed program for optimization of development and psychocorrection of social expectations of personality has become an effective, guided tool for solving a number of important social economic problems of the present, which lie in the sphere of interaction «institution of higher education professional activity».

Keywords: social expectations of personality; optimization of social expectations; psychocorrection of social expectations; project «Leader's School»; model of the expected future. 


\title{
Впровадження програми оптимізації розвитку соціальних очікувань особистості (на прикладі проекту «Школа лідера»).
}

\section{I. Попович}

\author{
Херсонський державний університет, Херсон, Україна
}

\begin{abstract}
У статті вперше представлено повний цикл від розробки і впровадження до висвітлення та аналізування результатів програми оптимізації розвитку та психокорекції соціальних очікувань особистості на прикладі проекту «Школа лідера». Подано ретроспективне і порівняльне аналізування досвіду впровадження проекту. Розкрито змістову сутність етапів розробки програми, досліджено психологічні змістові параметри соціальних очікувань особистості. Проаналізовано значну кількість психологічних змістових параметрів, що відносяться до мотиваційної структури особистості, сенсожиттєвих орієнтацій, суб'єктного контролю і експектометричних ознак. Авторська позиція полягає у тому, щоб розроблена програма оптимізації розвитку та психокорекції соціальних очікувань особистості стала ефективним, керованим засобом вирішення низки важливих суспільно-економічних проблем сьогодення, які лежать в площині взаємодії «заклад вищої освіти - професійна діяльність».
\end{abstract}

Ключові слова: соціальні очікування; оптимізація соціальних очікувань; психокорекція соціальних очікувань; проект «Школа лідера»; модель очікуваного майбутнього.

\section{Вступ}

Створення та апробація програм оптимізації розвитку та психокорекції соціальних очікувань для різних типів груп, зокрема навчальної, проектної, співробітників супермаркету, торгової команди, бригади вантажників, команди розробників веб-сайтів та ін. - показали, що такого роду проекти є дієвим і ефективним засобом вирішення нагальних проблем організацій-ініціаторів, пов'язаних з підбором, відбором, добором і комплектацією персоналу, пошуком талантів і наповненням кадрового резерву. Оптимізація розвитку рівнів соціальних очікувань та їх змістових психологічних параметрів $\epsilon$ важливих науковим інструментом у розв'язанні зазначених завдань. Апробація дала можливість акцентувати увагу на низці організаційно-процесуальних перешкод, які необхідно подолати для отримання максимальної економічної вигоди на вкладений ресурс. Програма оптимізації розвитку та психокорекції передбачала створення умов, що сприятимуть розгляду досліджуваного як суб'єкта поведінки i діяльності, здатного розвивати свій внутрішній суб'єктивний світ, змінювати ставлення до себе і оточуючих. Це дозволило прийти до розуміння, що ключовим є створення умов, які дозволять суб'єкту цілеспрямовано планувати, будувати і спрямовувати власні дії, вчинки, зусилля у відповідності з особистісно значущою метою та актуальними потребами.

У попередніх наукових пошуках (Popovych, 2002) розкрито соціально-психологічну сутність очікувань особистості, подано концептуальні положення (Boryshevskiy, 2012; Lomov, 1984; Maksimenko, 2013), методологічні принципи, ключові тези програми оптимізації розвитку та психокорекції соціальних очікувань особистості (Lunov, 2016; Rubinshteyn, 1959; Tatenko, 2000), подано соціальні очікування як регулятор соціально-психологічної реальності (Рopovych, 2016), окреслено здатність конструювати особистістю модель очікуваного майбутнього (Popovych,
2015; Gergen, 1997). Висвітлення результатів впровадження програми оптимізації соціальних очікувань особистості на прикладі проекту «Школа лідера» $\epsilon$ спробою розкрити сутність всіх етапи розробленої програми від створення, апробації до впровадження в практику; дослідити процесуальні особливості впровадження, вивчити психологічні змістові параметри, акцентувати увагу на практичній значущості та соціально-економічній вигоді від реалізації програми.

\section{Мета статті}

полягає у висвітленні результатів впровадження програми оптимізації соціальних очікувань особистості на прикладі проекту «Школа лідера»; розкритті змістової сутності етапів розробленої програми; дослідженні психологічних змістових параметрів соціальних очікувань особистості.

\section{Методи та процедури дослідження}

Для досягнення поставленої мети використано комплекс методів дослідження:

- теоретичні методи: теоретичний аналіз наукових джерел, методи інтерпретації та узагальнення результатів теоретичних, емпіричних досліджень проблеми соціальних очікувань особистості;

- емпіричні методи: психодіагностичні методи (тест «Смисложиттєві орієнтації» (Дж. Крамбо та Л.Махолік, адаптація Д. О. Леонтьєва), опитувальник «Рівень суб'єктивного контролю» (Дж. Б. Роттер, адаптація Є. Ф. Бажина, Є. А. Голинкіної, О. М. Еткінда), опитувальник «Рівень домагань особистості» (В.К.Гербачевський), авторська соціометрична методика «Експектометрія», опитувальник «Рівень соціальних очікувань», контент-аналітичні методики «Очікувана ситуація» і «Реалізація очікувань»);

$$
\text { - методи формувального експерименту: }
$$
соціально-психологічний тренінг, моделювання 
соціального контексту міжособистісної взаємодії, психологічне консультування, психокорекційні вправи, післятренінговий супровід, лекція, бесіда, дискусія»;

- методи математичної обробки даних: Ткритерій Ф. Вілкоксона для порівняння отриманих емпіричних показників 3 їх подальшою якісною інтерпретацією та змістовим узагальненням. Статистичну обробку емпіричних даних і графічну презентацію результатів здійснено за допомогою статистичних програм SPSS v. 23.0 та MS Excel.

\section{Результати}

Програму оптимізації соціальних очікувань особистості, на базі якої було організовано проект «Школа лідера», вважаємо унікальним засобом переходу студентів закладів вищої освіти від освітньої діяльності до професійної. Запропонована програма дозволила розв'язати низку завдань: адаптація оптантів на робочих місцях; первинна професіоналізація фахівців, що продовжують здобувати рівень вищої освіти за заочною чи індивідуальною формою; зв'язок теорії з практикою; комплектування організації мотивованими співробітниками та ін. Впродовж 2015-2018 pp. у проекті «Школа лідера» взяли участь студенти другихчетвертих курсів різних факультетів Херсонського національного технічного університету, Херсонського державного університету, Херсонського державного аграрного університету та інших навчальних закладів м. Херсону, що охопило більше двох десятків спеціальностей. Загальна кількість бажаючих на початковій стадії склала $\mathrm{n}=674$. Даний проект було організовано п'ять разів. Кожного разу, студенти проходили відбір і до проекту допускали орієнтовно n=20-24 учасники. Загальна кількість учасників, що взяли участь в проекті склала $\mathrm{n}=112$. Проект «Школа лідера» передбачав курс тренінгів, низку консультаційних бесід та стажування на базі організаціїініціатора. На фінальній стадії працювала експертна комісія. До складу експертної комісії входили керівники напрямків, департаментів, топ-склад організації, ті, хто відбирав персонал у свій штат. Найкращі учасники запрошувалися експертами для проходження стажування на базі однієї 3 провідних комерційних організацій півдня України. Маємо досвід впровадження проекту в маркетингово-аналітичній організації ТОВ «МАК «Монополія», всеукраїнській мережі будівельногосподарських супермаркетів «33м2етра», комерційній організації ТОВ «Максі Трейд», логістичнодистрибюторській організації ТОВ «ЛДК», інтернетагентстві ТОВ «Везом» та ін. Особливість реалізації полягала у тому, що всі групи були тимчасовими та штучно створеними, за змістовими психологічними особливостями згуртованості знаходилися на дифузній стадії розвитку ціннісно-орієнтаційної єдності як колективу і були наділені первинними його ознаками. Незважаючи на такі низькі динамічні характеристики згуртованості, ï учасниками були «надміру цілеспрямовані» та «максимально мотивовані» оптанти - студенти других-четвертих курсів. Перший курс ми не залучали, бо такою була домовленість з деканатами та організаційно-навчальними відділами закладів вищоі освіти. Унікальність програми полягала у тому, що найкращі учасники мали можливість пройти стажування на базі організації, що дозволило порівняти соціокультурний простір закладу вищої освіти 3 соціокультурним простором приватної організації, створювало сприятливі умови для дослідження збігу очікувань майбутніх фахівців з реаліями на ймовірних робочих місцях. Отже, впровадження програми «Школа лідера» дозволило підготувати студентів-стажерів до отримання очікуваного результату - реалізації бажаної мети, або її спростувати і продовжити навчання у стінах вузу.

Розкриємо деякі особливості розробки програми тренінгових занять «Школа лідера». Мета реалізації програми полягала в оптимізації розвитку соціальних очікувань «надміру мотивованих» студентів до професійної діяльності в організації. На стадії організації проекту студенти проявили активність і бажання взяти участь у «Школі лідера», кращі 3 них були відібрані та об'єднані у проектну групу. Тренінгові заняття проводилися у другій половині дня, після традиційного навчання студентів, орієнтовно два-три рази на тиждень.

Для учасників «Школи лідера» умовами проекту передбачено двотижневе стажування на майбутніх робочих місцях за кошти організації-ініціатора, матеріальне заохочення та подальше повне або часткове працевлаштування. Це додатково стимулювало учасників до досягнення очікуваного результату. Часткове працевлаштування передбачало проектну зайнятість, але звісно, якщо це не суперечило правилам внутрішнього розпорядку організації. Для порівняння психологічних змістових параметрів соціальних очікувань на початковій стадії було здійснено констатувальний зріз.

Програма тренінгових занять «Школа лідера» представляла поєднання шести тренінгових занять, загальним обсягом 24 години, які проводилися після традиційного навчання, впродовж двох місяців. Як показала практика, доцільно формувати дві тренінгові групи по 10-12 учасників. Представимо програму тренінгових занять проекту «Школа лідера» у табл. 1.

Метою проведених тренінгових занять: «Моделі і стратегії ефективної комунікації в міжособистісній взаємодії. Обізнаність про попередній перебіг подій», «Тайм-менеджмент. Особистісна ефективність. Темпоральні властивості особистості», «Публічний виступ. Соціальні очікування учасників комунікації», «Розв'язання конфліктів. Стресостійкість. Невиправдані соціальні очікування особистості», «Формування лідерських якостей. Соціальні очікування лідера. Експектометричний коефіцієнт», «Ефективні стратегії в професійній діяльності. Очікуваний результат» - було сформувати готовність учасників до майбутньої професійної діяльності, оптимізувати розвиток соціальних очікувань стажерів, збагатити їх прикладними інструментами для вирішення завдань на початковій стадії професіоналізації, розширити уявлення про деякі змістові психологічні особливості професійної діяльності, сформувати позитивний очікуваний образ майбутньої професійної діяльності. 
Програма тренінгових занять проекту «Школа лідера»

\begin{tabular}{|c|c|c|c|}
\hline № & Розгорнута тематика тренінгових занять & Методи і форми роботи & $\begin{array}{l}\text { Обсяг, } \\
\text { год. }\end{array}$ \\
\hline 1. &  & $\begin{array}{l}\text { вступне слово, } \quad \text { соціально-психологічний } \\
\text { тренінг, тренувальні вправи, психокорекційні } \\
\text { вправи }\end{array}$ & 4 \\
\hline 2. & $\begin{array}{lcc}\text { «Тайм-менеджмент. } & \text { Особистісна } & \text { ефективність. } \\
\text { Темпоральні властивості особистості» } & \\
\end{array}$ & $\begin{array}{l}\text { тренувальні вправи, } \\
\text { діяльності, інтроспекція }\end{array}$ & 4 \\
\hline 3. & $\begin{array}{l}\text { «Публічний виступ. Соціальні очікування учасників } \\
\text { комунікації» }\end{array}$ & ділова гра, тренувальні вправи, доповідь & 4 \\
\hline 4. & $\begin{array}{l}\text { «Розв’язання конфліктів. Стресостійкість. Невиправдані } \\
\text { соціальні очікування особистості» }\end{array}$ & $\begin{array}{l}\text { тренувальні вправи, психокорекційні вправи, } \\
\text { опитувальник }\end{array}$ & 4 \\
\hline 5. & $\begin{array}{l}\text { «Формування лідерських якостей. Соціальні очікування } \\
\text { лідера. Експектометричний коефіцієнт» }\end{array}$ & $\begin{array}{l}\text { мозковий штурм, презентація, ділова гра, } \\
\text { тренувальні вправи, експектометрія }\end{array}$ & 4 \\
\hline 6. & $\begin{array}{l}\text { «Ефективні стратегії в професійній діяльності. Очікуваний } \\
\text { результат» }\end{array}$ & $\begin{array}{l}\text { SWOT-аналіз, тренувальні вправи, заключне } \\
\text { слово }\end{array}$ & 4 \\
\hline \multicolumn{2}{|c|}{ Всього: } & 24 & \\
\hline
\end{tabular}

У програмі застосовано такі методи і форми роботи: соціально-психологічний тренінг, тренувальні та психокорекційні вправи, індивідуальні та фронтальні бесіди, мозковий штурм, аналіз результатів діяльності, інтроспекція, експектометрія, доповідь, ділові ігри та ін.

Розробка i впровадження програм оптимізації розвитку та психокорекції соціальних очікувань особистості, дозволили на контрольному етапі експерименту акцентувати увагу на об'єктивних i суб'єктивних критеріях оцінювання. Суб'єктивними критеріями були думки, висловлювання, враження досліджуваних від реалізації програм оптимізації розвитку та психокорекції соціальних очікувань особистості. Об'єктивними критеріями ефективності виступали дані, визначені за психодіагностичними методиками.

Розглянемо результати впровадження програми Особливістю впровадження такого типу програм $\epsilon$ те, що дані групи $\epsilon$ проектними i контрольна група відсутня. Порівнювати зі студентськими групами чи схожими фактично працюючими трудовими колективами недоцільно, оскільки перед проектною групою стоять дещо інші завдання. У такому випадку виходимо зі значущості та величини позитивного «зсуву», що мав місце в експериментальній групі, а також загальної мети проведення такого роду заходів. Кожне наступне проведення програми дозволило порівнювати отримані результати 3 результатами попередніми і вносити корективи. Однотипних проектів не було. Тому порівняння проведеного проекту 3 попередніми також не вважаємо, з наукової точки зору, екологічно валідним та достовірним. Отже, орієнтуємося на зміни, що мали місце після формувального експерименту, порівнюємо дані зафіксовані констатувальним та контрольним зрізами.

Перейдемо до аналізування результатів, що характеризують соціальні очікування як процес i результат психічної регуляції поведінки. Розглянемо основні результати впровадження програми на основі порівняння показників соціальних очікувань досліджуваних до і після формувального експерименту (див. табл. 2).

Таблиця 2

Порівняння показників соціальних очікувань експериментальної групи до і після формувального експерименту

\begin{tabular}{|c|c|c|c|c|c|c|c|c|}
\hline \multirow{2}{*}{ № } & \multirow{2}{*}{$\begin{array}{c}\text { Показник соціальних } \\
\text { очікувань }\end{array}$} & \multirow{2}{*}{$\begin{array}{c}\text { Рівень } \\
\text { соціальни } \\
\text { х } \\
\text { очікувань } \\
\end{array}$} & \multicolumn{2}{|c|}{$\begin{array}{c}\text { До експерименту } \\
\mathrm{n}=24\end{array}$} & \multicolumn{2}{|c|}{$\begin{array}{c}\text { Після } \\
\text { експерименту } n=24\end{array}$} & \multirow[t]{2}{*}{$\begin{array}{c}\text { Т-критерій } \\
\text { Ф.Вілкоксона } \\
\text { (сума рангів), } \mathrm{T}_{n},{ }^{*} \mathrm{~T}_{\mathrm{H}}{ }^{* *}\end{array}$} & \multirow{2}{*}{$\begin{array}{c}\text { Коеф. } \\
\text { значущості, } \\
\text { p } \leq 0,05\end{array}$} \\
\hline & & & $\mathrm{n}$ & $\%$ & $\mathrm{n}$ & $\%$ & & \\
\hline \multirow{3}{*}{1} & \multirow{3}{*}{$\begin{array}{c}\text { Рівень обізнаності про } \\
\text { передбачуваний перебіг } \\
\text { подій, ОП }\end{array}$} & високий & 6 & 25,00 & 9 & 37,50 & \multirow{3}{*}{$\begin{array}{c}\text { позитивні } \\
68,00 \\
\text { негативні } \\
12,00\end{array}$} & \multirow{3}{*}{0,005} \\
\hline & & середній & 15 & 62,50 & 14 & 58,33 & & \\
\hline & & низький & 3 & 12,50 & 1 & 4,17 & & \\
\hline \multirow{3}{*}{2} & \multirow{3}{*}{$\begin{array}{c}\text { Рівень очікуваного } \\
\text { ставлення до учасників } \\
\text { міжособистісної взаємодії, } \\
\text { оС. }_{\text {o }}\end{array}$} & високий & 5 & 20,83 & 3 & 12,50 & \multirow{3}{*}{$\begin{array}{c}\text { позитивні } \\
16,00 \\
\text { негативні } \\
44,00 \\
\end{array}$} & \multirow{3}{*}{0,138} \\
\hline & & середній & 17 & 70,83 & 19 & 79,17 & & \\
\hline & & низький & 2 & 8,33 & 2 & 8,33 & & \\
\hline \multirow{3}{*}{3} & \multirow{3}{*}{$\begin{array}{c}\text { Рівень очікуваних } \\
\text { результатів діяльності, } \\
\text { ОР }\end{array}$} & високий & 7 & 29,17 & 11 & 45,83 & \multirow{3}{*}{$\begin{array}{c}\text { позитивні } \\
72,00 \\
\text { негативні } \\
8,00\end{array}$} & \multirow{3}{*}{0,003} \\
\hline & & середній & 16 & 66,67 & 12 & 50,00 & & \\
\hline & & низький & 1 & 4,17 & 1 & 4,17 & & \\
\hline \multirow{3}{*}{4} & \multirow{3}{*}{$\begin{array}{c}\text { Рівень соціальних } \\
\text { очікувань, } \mathrm{PCO}_{\text {o }}\end{array}$} & високий & 15 & 62,50 & 17 & 70,83 & \multirow{3}{*}{$\begin{array}{c}\text { позитивні } \\
102,00 \\
\text { негативні } \\
6,00 \\
\end{array}$} & \multirow{3}{*}{0,005} \\
\hline & & середній & 7 & 29,17 & 5 & 20,83 & & \\
\hline & & низький & 2 & 8,33 & 2 & 8,33 & & \\
\hline
\end{tabular}

Примітка. Тп* - сума позитивних рангів Т-критерія Ф. Вілкоксона; Тн** - сума негативних рангів Т-критерія Ф. Вілкоксона. 
Порівняння показників соціальних очікувань експериментальної групи до і після формувального експерименту підтвердило ефективність програми тренінгових занять «Школа лідера». 3 таблиці видно, що зафіксовано значущі позитивні зміни показника обізнаності про передбачуваний перебіг подій (Тп=68,00; p=0,005), значущі позитивні зміни очікуваних результатів діяльності (Тп=72,00; p=0,003) і значущі позитивні зміни показника рівня соціальних очікувань досліджуваних (Тп=102,00; p=0,005). Незначущими $\epsilon$ позитивні зміни показника очікуваного ставлення до учасників міжособистісної взаємодії (Тп=16,00; p=0,138). Зазначаємо, що наша експериментальна група не стала виключенням і продемонструвала схожі результати порівняння параметрів соціальних очікувань особистості з усіма попередніми. Звісно, що першого разу отримані низькі результати нас неприємно вразили. Згодом зрозуміли і дали пояснення таким рівням, зокрема показникам соціально-психологічних особливостей очікуваного ставлення особистості до учасників міжособистісної взаємодії.

Констатуємо, що реалізована програма забезпечила значущу різницю «зсувів» у складовій соціальнопсихологічних особливостей обізнаності особистості про передбачуваний перебіг подій (Тп=68,00; Тн=12,00; при $\mathrm{p} \leq 0,05)$ та складовій соціально-психологічних особливостей регуляції особистістю очікуваних результатів діяльності (Тп=72,00; Тн=8,00; при $\mathrm{p} \leq 0,03$ ), що $\mathrm{i}$ сприяло значущим змінам показника рівня соціальних очікувань досліджуваного (Тп=102,00; $\mathrm{T}_{\mathrm{H}}=6,00$; при $\left.\mathrm{p} \leq 0,05\right)$. Отримано негативну різницю «зсувів» у складовій соціально-психологічних особливостей очікуваного ставлення особистості до учасників міжособистісної взаємодії (Тп=16,00; $\left.\mathrm{T}_{\mathrm{H}}=44,00 ; \mathrm{p} \geq 0,05\right)$. Припускаємо, що реалізація програми посприяла позитивним динамічним змінам когнітивної і поведінкової готовності до передбачуваного перебігу подій. Учасники проектної групи отримали можливість оцінити майбутню перспективу, осмислити змістові та організаційні особливості майбутньої професійної діяльності, «приміряти перспективу», що внесло корективи у їхні соціальні очікування, і позначилося на конструюванні моделі очікуваного майбутнього. Не виключаємо, що значна частина студентів могла виявитися неготовою до швидкої зміни статусу, хоча і висловлювала свої прагнення і проявила достатню рішучість. Наші спостереження дозволили стверджувати, що процес формування емоційної готовності вимагає тривалих зовнішніх інтервенцій. Зазначимо, що у попередніх експериментальних та контрольних групах ми отримували схожі значення суми негативних рангів. Подамо результати порівняння показників суб'єктного контролю, загальної осмисленості життя, мотиваційної структури особистості експериментальної групи до і після формувального експерименту, визначені за допомогою Т-критерію Ф. Вілкоксона (див. табл. 3).

Таблищя 3

Порівняння показників досліджуваних ознак експериментальної групи до і після формувального експерименту

\begin{tabular}{|c|c|c|c|}
\hline № & Показник досліджуваних ознак & $\begin{array}{c}\text { Т-критерій Ф.Вілкоксона } \\
\text { (сума рангів), } \\
\mathrm{T}_{\pi},{ }^{*} \mathrm{~T}_{\mathrm{H}} * * \\
\end{array}$ & $\begin{array}{c}\text { Коеф. значущості, } \\
\text { p } \leq 0,05\end{array}$ \\
\hline 1 & 2 & 3 & 4 \\
\hline 1. & Загальна інтернальність, $\mathrm{I}_{3}$ & $\begin{array}{l}\text { позитивні 72,50 } \\
\text { негативні 15,50 }\end{array}$ & 0,041 \\
\hline 2. & Інтернальність в галузі досягнень, $\mathrm{I}_{д}$ & $\begin{array}{c}\text { позитивні } 118,00 \\
\text { негативні } 18,00\end{array}$ & 0,007 \\
\hline 3. & Інтернальність в галузі невдач, $\mathrm{I}_{\text {н }}$ & $\begin{array}{c}\text { позитивні } 27,00 \\
\text { негативні } 2,50\end{array}$ & 0,032 \\
\hline 4. & Інтернальність у сімейних стосунках, Ic & $\begin{array}{c}\text { позитивні 42,50 } \\
\text { негативні 2,50 }\end{array}$ & 0,011 \\
\hline 5. & Інтернальність в галузі виробничих відносин, I & $\begin{array}{c}\text { позитивні } 57,00 \\
\text { негативні 9,00 }\end{array}$ & 0,021 \\
\hline 6. & Інтернальність стосовно здоров'я і хвороб, $\mathrm{I}_{\mathrm{x}}$ & $\begin{array}{l}\text { позитивні } 47,00 \\
\text { негативні } 19,00\end{array}$ & 0,133 \\
\hline 7. & Цілі в житті & $\begin{array}{c}\text { позитивні } 118,00 \\
\text { негативні } 17,00\end{array}$ & 0,008 \\
\hline 8. & Процес & $\begin{array}{c}\text { позитивні } 16,00 \\
\text { негативні } 1,00\end{array}$ & 0,040 \\
\hline 9. & Результат & $\begin{array}{l}\text { позитивні } 96,00 \\
\text { негативні } 22,00\end{array}$ & 0,033 \\
\hline 10. & Локус контролю - Я & $\begin{array}{c}\text { позитивні } 58,00 \\
\text { негативні } 6,00\end{array}$ & 0,021 \\
\hline 11. & Локус контролю - життя & $\begin{array}{l}\text { позитивні } 38,00 \\
\text { негативні } 17,00\end{array}$ & 0,226 \\
\hline 12. & Загальний Ож & $\begin{array}{c}\text { позитивні } 122,00 \\
\text { негативні } 28,00 \\
\end{array}$ & 0,025 \\
\hline 13. & Внутрішній мотив & $\begin{array}{l}\text { позитивні } 68,00 \\
\text { негативні } 15,00\end{array}$ & 0,021 \\
\hline
\end{tabular}

Volume 29, Number 5, 2018 


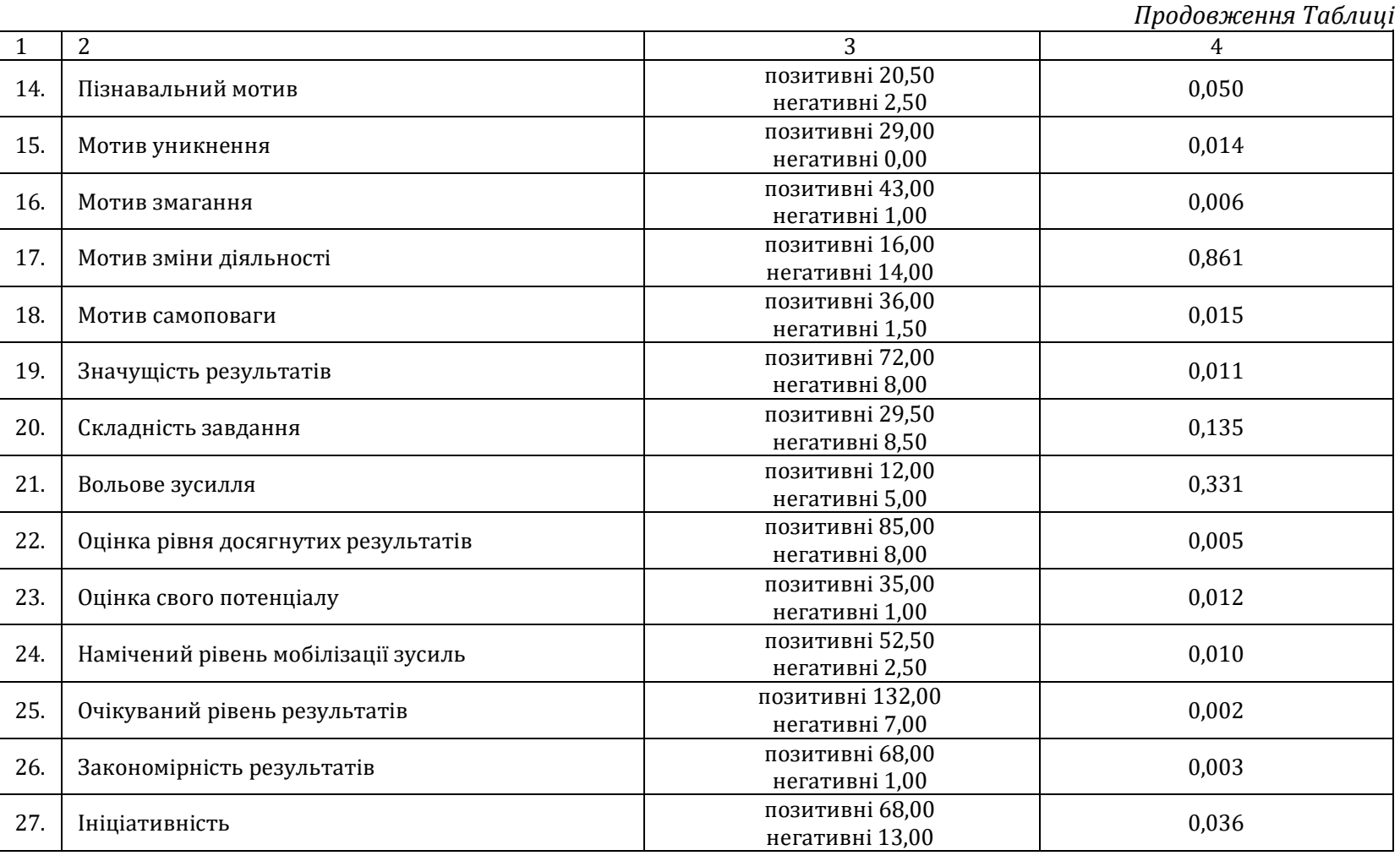

Примітка. Тп* - сума позитивних рангів Т-критерія Ф. Вілкоксона; Тн** - сума негативних рангів Т-критерія Ф. Вілкоксона.

Порівняння експерименту свідчить, що очікувано значущими є позитивні зміни в показниках загальної інтернальності (Тп=72,50; p=0,041) та їі складових, крім показника інтернальності стосовно здоров'я і хвороб (Тп=47,00; $\mathrm{p}=0,133)$. Позитивно значущі зміни $\epsilon$ в показниках загальної осмисленості життя (Тп=122,00; $=0,025)$ та її показниках, за виключенням показника «локус контролю - життя» (Тп=38,00; $=0,226)$.

Позитивні значущі зміни мають місце в значній частині складових мотиваційної структури особистості, виключення складають показники: пізнавальний мотив (Тп=20,50; p=0,050), мотив зміни діяльності (Тп=16,00; $\mathrm{p}=0,861)$, складність завдання $(\mathrm{T} п=29,50 ; \mathrm{p}=0,135)$. Отримані результати, що зведені в табл. 3 , свідчать про значущі зміни в досліджуваних експериментальної вибірки, які були досягнуті реалізацією програми тренінгових занять «Школа лідера».

Перейдемо до аналізу результатів, що характеризують соціальні очікування як процес i результат конструювання, й відображення особистістю соціальної дійсності. Подамо зміни показників властивостей соціальних очікувань досліджуваних до і після формувального експерименту (див. табл. 4).

Порівняння показників властивостей соціальних очікувань експериментальної групи до і після формувального експерименту показує зміни, що відбулися в експериментальній групі після формувального експерименту.

3 таблиці видно, що зафіксовано значущі позитивні зміни у всіх дихотомічних парах властивостей соціальних очікувань особистості: інтернальність / екстернальність (Тп=68,00; p=0,004), активність / пасивність (Тп=38,00; $\mathrm{p}=0,009)$, відкритість / закритість (Тп=22,00; p=0,025), адекватність / неадекватність (Тп=58,00; p=0,004). Отримано значущі зміни у показниках дихотомічної пари властивостей «інтернальність / екстернальність», що свідчить про налаштованість на результат, який учасники проекту прагнуть отримати.

Такі показники радше вважаємо виключенням, оскільки на стадії комплектування проектної групи до неї потрапили всі інтернали, а на етапі формувального експерименту впроваджена програма тільки підсилила інтернальну складову соціальних очікувань учасників. Досвід проведення попередніх проектів «Школа лідера» показав високу активність інтерналів і значний відсоток проходження їх на етап стажування. 
Порівняння показників властивостей соціальних очікувань експериментальної групи до і після

Таблиця 4 формувального експерименту

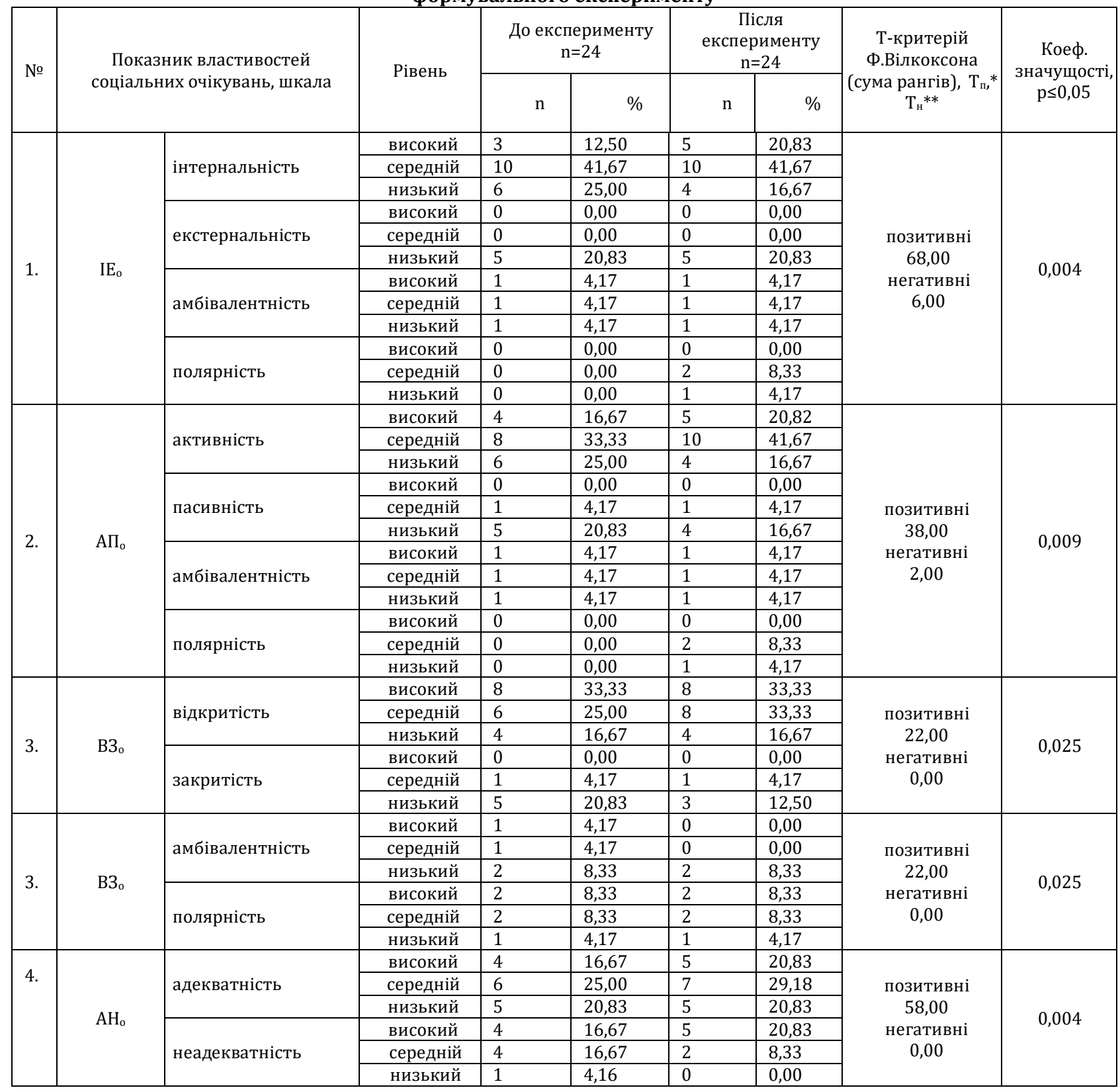

Примітка. Тп* - сума позитивних рангів Т-критерія Ф. Вілкоксона; Тн** - сума негативних рангів Т-критерія Ф. Вілкоксона.

Тільки зараз можемо рекомендувати організаторам звертати увагу на учасників, які $\epsilon$ екстерналами i володіють значним потенціалом. Інші високі показники властивостей є очевидними і прогнозовано значущими. Подамо результати порівняння показників експектометричних ознак експериментальної групи до і після формувального експерименту, визначені за допомогою Т-критерію Ф. Вілкоксона (див. табл. 5).
Порівняння показників експектометричних ознак експериментальної групи до і після формувального експерименту свідчить про високі значущі позитивні зміни: коефіцієнта очікувань (Тп=102,00; $\mathrm{p}=0,004)$, експектометричного статусу (Тп $=68,00 ; \mathrm{p}=0,008)$, рівня адекватності самоочікувань (Тп=42,00; $\mathrm{p}=0,033)$ та коефіцієнта взаємоочікуваних виборів (Тп=38,00; $\mathrm{p}=0,011$ ) 
Порівняння показників експектометричних ознак експериментальної групи до і після формувального експерименту

\begin{tabular}{|c|l|c|c|}
\hline № & \multicolumn{1}{|c|}{ Показники експектометричної ознаки } & $\begin{array}{c}\text { T-критерій Ф.Вілкоксона } \\
\text { (сума рангів), } \\
\mathrm{T}_{\text {п }}^{*} \mathrm{~T}_{\mathrm{H}} * *\end{array}$ & $\begin{array}{c}\text { Коеф. значущості, } \\
\mathrm{p} \leq 0,05\end{array}$ \\
\hline 1. & Коефіцієнт очікувань, E & $\begin{array}{c}\text { позитивні } 102,00 \\
\text { негативні } 2,00\end{array}$ & $\begin{array}{c}\text { позитивні } 68,00 \\
\text { негативні } 8,00\end{array}$ \\
\hline 2. & Експектометричний статус, ES & $\begin{array}{c}\text { позитивні } 42,00 \\
\text { негативні } 7,50\end{array}$ & 0,003 \\
\hline 3. & Рівень адекватності самоочікувань, А & позитивні 38,00 \\
\hline 4. & Коефіцієнт взаємоочікуваних виборів, $\mathrm{E}_{\text {вр }}$ & 0,033 \\
\hline
\end{tabular}

Примітка. Тп* - сума позитивних рангів Т-критерія Ф. Вілкоксона; Тн** - сума негативних рангів Т-критерія Ф. Вілкоксона.

\section{Обговорення}

Пояснюємо такі значні зміни тим, що проектна група на стадії створення, при проведенні констатувального зрізу, показала дуже низькі показники експектометричних ознак та параметрів, що характеризують їі як колектив. Високий потенціал учасників проекту, робота у тренінговій групі, колективне прагнення об'єднатися перед невідомим, своєрідний соціально-психологічний ефект «небезпеки» (адже мета у кожного учасника була індивідуальна), сприяли значущим змінам параметрів експектометричних ознак. Маємо підстави стверджувати, що формувальні впливи програми тренінгових занять «Школа лідера» сприяли оптимізації розвитку та психокорекції соціальних очікувань студентів закладів вищої освіти, а це у свою чергу забезпечувало їх ефективну адаптацію до професійної діяльності на майбутніх робочих місцях. Позитивним результатом впровадження програми вважаємо запрошення найкращих учасників на стажування 3 подальшим працевлаштуванням. Можемо констатувати, що після першого проекту організація-ініціатор запросила на стажування 13 учасників, другий проект 18 учасників, третій - 9 учасників, четвертий 15 і п'ятий проект - 12 учасників. Значна частина запрошених учасників прийняла запрошення від організаціїініціатора і пройшла стажування $\mathrm{n}=67 ; 59,82 \%$.

Результати впровадження зазначеної програми показали високий рівень валідності попередньо розроблених діагностичних процедур та ефективність застосованих методів формувального впливу щодо оптимізації розвитку та психокорекції соціальних очікувань особистості. Ефективність запропонованої програми доведена: позитивними змінами у показниках рівня сформованості соціальних очікувань та його складових; підвищенням показників властивостей соціальних очікувань, таких як інтернальність, активність, відкритість та адекватність; зростанням інтернальності у сфері виробничих стосунків та загальної інтернальності; підвищенням показників загальної осмисленості життя; зростанням орієнтації на цілі в житті та результативність життя або задоволеність самореалізацією.

\section{Висновки}

Висвітлено результати впровадження програми оптимізації соціальних очікувань особистості на прикладі проекту «Школа лідера». Розкрито психологічні змістові параметри досліджуваного феномену. Проаналізовано значну кількість психологічних змістових параметрів, що відносяться до мотиваційної структури особистості, сенсожиттєвих орієнтацій, суб'єктного контролю й експектометричних ознак. Такий спектр психологічних змістових параметрів достатньо розкриває досліджуваний феномен і дозволяє зробити програму оптимізації ефективним, керованим засобом вирішення низки важливих суспільно-економічних проблем сьогодення. Найближчі перспективи наукових пошуків вбачаємо в дослідженні психологічних змістових параметрів конструювання особистістю моделі очікуваного майбутнього.

\section{Лiтература / References}

Boryshevskiy, M. Y. (2012). Osobistist u vimirah samosvidomosti: monografiya. Personality in dimensions of consciousness, 608. [in Ukrainian].

Lomov, B. F. (1984). Metodologicheskie i teoreticheskie problemyi psihologii Methodological and theoretical problems of psychology, 444. [in Russian]

Lunov, V.E (2016). Psihologiya kognitivnogo stanovlennya profesionala (na prikladi fahivtsiv sistemi ulyudina-lyudina). Psychology of cognitive formation of a professional (on the example of the specialists of the system «man-man»), 250. [in Ukrainian].

Maksimenko, S. D. (2013). Psihologiya uchinnya lyudini: genetiko-modelyuyuchiy pidhid. Psychology of human learning: a genetic modeling approach, 592. [in Ukrainian].

Popovych, I. S. (2015). Konstruyuvannya osobististyu modeli ochikuvanogo maybutnogo Designing the model of the expected future. Naukoviy visnik HDU. - Seriya psihologichni nauki : zb. nauk. prats HDU, 145-154. [in Ukrainian].

Popovych, I. S. (2016). Sotsialni ochikuvannya osobistosti yak regulyator sotsialnopsihologichnoi realnosti. Social expectations of the personality as a regulator of socio-

psychological reality. Aktualni problemi psihologii : zb. nauk. prats Institutu psihologii imeni G. S. Kostyuka NAPN Ukraini, 138-143. [in Ukrainian].

Popovych, I. S. (2002). Fenomen tsinnisno-orientatsiynoii ednosti v grupi kursantiv. The phenomenon of value-orientation unity in the group of students. Problemi zag. ta ped. psihol.: zb. nauk. prats In-t. psihol. imeni G. S. Kostyuka APN Ukraiini, IV(5), 203209. [in Ukrainian].

Rubinshteyn, S. L. (1959). Printsipyi i puti razvitiya psihologii. Principles and ways of development of psychology, 354. [in Russian].

Tatenko, V. O. (2000). Pro teoretiko-metodologichni zasadi psihologichnogo doslidzhennya suspilnih yavisch. On theoretical and methodological foundations of psychological research of social phenomena. Naukovi studii iz sotsialnoi ta polit. psihol. : zb. Statey, 2(5), 19-26. [in Ukrainian].

Gergen, K. J. (1997). Social psychology as cosial construction: The emerging vision. The message of social psychology: Perspectives on mind of cosiety, 113-128. [in English]. 